\title{
Functions of the hospital in a leprosy training institution
}

\section{TAYE TADESSE}

All Africa Leprosy and Rehabilitation Training Centre, P.O. Box 165, Addis Ababa, Ethiopia

The key words here are hospital and training. What then is a hospital? The Webster's New Collegiate Dictionary defines it in three ways:

1. A charitable institution for the needy, aged, infirm or young.

2. An institution where the sick or injured are given medical or surgical care.

3. A repair shop for specified small objects (Clock Hospital) (1) .

This presentation will take it in its second definition.

The ALERT hospital provides medical, surgical and ophthalmological services primarily to leprosy patients, but also to cases with skin diseases and a limited number with other diseases that fall within the expertise we have. These services are essential both for the clinical care of patients and the training provided at ALERT.

Training is an essential element already in ALERT's name. Whom do we train? What? And why? Its purpose is defined in the agreement between the Ministry of Health of Socialist Ethiopia (Ministry) and the All Africa Leprosy and Rehabilitation Training Centre (ALERT) including the Armauer Hansen Research Institute (AHRI) which states: "In accordance with the terms of this agreement ALERT under the auspices of the Ministry, shall continue the medical and administrative management in order to keep up to the standard necessary for continuation of activities as an International Training centre where men and women shall be trained in all aspects of leprosy with special emphasis on the training of qualified teachers and leaders in the fields of control, medical and surgical treatment, and physical and social rehabilitation of sufferers 
from leprosy particularly as it applies to the African Continent" (2).

Thus, training in the field of leprosy which includes the transfer of task oriented skills to our trainees, is one of the important obligations of the Hospital. In addition to this, we have clinical service and clinical research. The latter complements, augments and strengthens the service and training functions of the Institution.

What are the problems of leprosy patients that need the services of a hospital? Leprosy is primarily a disease of peripheral nerves. Infection with

often results in induction of cell mediated immune reactions and production of circulating antibodies (3). These immune responses are the basis for the problems that leprosy patients have, and many patients go into a hypersensitivity reaction that results in nerve damage. The loss of function of sensory and motor nerves leads to different types and degrees of deformities, injuries and ulcerations. It is to manage these reactions and the outcome of nerve damage that we need a hospital. In the hospital then, trainees observe and learn how these problems are handled to eventually rehabilitate the patients to become useful members in their society.

What do we need? We need to have

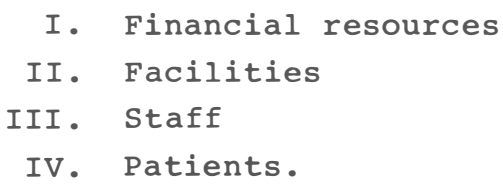

I. Financial Resources:

Thanks to the continued support by the Ministry of Health of Socialist Ethiopia, ILEP and other sponsors of ALERT, we have had a sound financial basis for running the Hospital. The annual Hospital budget has increased from Birr 834,545 in 1966 to Birr 1,544,186 in 1985 . 
II. Facilities:

We have 207 beds for divisions of medicine, surgery and ophthalmology with 104,90 and 13 beds respectively. Up to 208 of these beds are used for non-leprosy patients. Referal of non-leprosy patients to the various divisions of the hospital and the out-patient clinics is essential to meet pressing needs for clinical care and for training purposes providing a varied patient population for demonstrations and training in differential diagnosis. We have three operation days for surgery and two for ophthalmology. The operating threatre is well equipped with two operating rooms.

The out-patient services are organized in different clinics:

\section{A. Medical Clinics:}

1. Red Medical Clinic.

Leprosy patients who have developed reactions are referred to this clinic for follow-up after initial treatment as in-patients. Patients suspected of having a reaction are also assessed in this clinic. These patients will eventually be referred to their respective local clinics when their acute problem is controlled.

2. Diagnostic Clinic.

This is a daily clinic where all patients with skin diseases including new leprosy patients come to. It has three examination rooms, two of which can accommodate two doctors. The third room is for group demonstration of interesting cases. This clinic is extensively used for teaching purposes, particularly to learn differential diagnosis and to recognize leprosy cases among large groups of unselected patients with skin disorders.

3. New Case Clinic.

This is where all newly diagnosed leprosy patients go to with the results of all primary investigations. There they 
are classified and plans made on their future management. It is held three mornings a week.

4. Sick Out-patient Clinic.

This is a daily clinic where leprosy patients and their immediate relatives with medical problems other than leprosy are attended to. The relatives could have gone to any general hospital had it not been for the strong stigma that prevails.

\section{B. Surgical Clinics:}

1. Ulcer Clinic.

Plantar ulcers secondary to anaesthesia is a common problem in leprosy patients. Such patients are taken care of in their respective clinics, but those who need to be assessed by surgeons are referred to this once weekly clinic for management.

2. Leprosy/non-leprosy surgical clinic.

This clinic held once a week attends to leprosy patients for reconstructive surgery and non-leprosy patients referred from other hospitals for similar evaluation. Priority is given to leprosy patients.

3. Club-foot/polio clinic.

Children with congenital deformities like club-foot and with post-polio paralysis come to this once weekly clinic for assessment, preparation and corrective surgery.

\section{Ophthalmological clinic:}

This clinic is held three times a week and leprosy as well as non-leprosy patients with eye problems are attended to. 
D. Dental Clinic:

This is a daily clinic where leprosy patients and their immediate relatives come to. Most are referred from other out-patient clinics and some are appointed from the wards for preventive and curative services.

\section{Supportive Services:}

1. Orthopaedic appliances workshop.

Anaesthesia of the foot is an important condition that deserves a lot of attention from all parties concerned in leprosy work. As these individuals are ready made candidates for trauma every day of their life, the provision of protective footwear is crucial in the protection of their feet. To this end, different types of footwear for different grades of foot deformity are made and distributed. Different appliances for different levels of amputations and different deformities are made.

2. Physiotherapy

Reconstructive surgery without an effective physiotherapy service will invariably fail. Thus we have this service to prepare patients for surgery and to train those operated upon. In addition nerve function assessments are done here, being crucial in the choice of treatment. This section is also extensively involved in in-service training.

3. Medico-social service.

Important medico-social information is provided by this section on all admitted patients. This exercise helps to sort out those patients who cannot afford to pay the nominal fees for footwear and bus tickets back home. It also helps in planning the sort of treatment to be given and in writing transfer letters. Such patients are supported financially from the ALERT wellfare fund. This section is also involved in the social rehabilitation activities in the surrounding village and in teaching 
activities related to social aspects of leprosy.

4. Ergotherapy.

Anaesthesia of the hands and the cornea is another disability in leprosy patients which endangers them to trauma and burns. Such patients must have appropriate training that helps them in their day to day life. It is to serve this purpose that we have the ergotherapy or occupational therapy service. Here the ALERT radio, the cooking class demonstration tukule, and the puppet show facilities have been instrumental in the delivery of appropriate health education.

5. Laboratory.

The laboratory provides essential services both regarding diagnosis, classification, and follow-up of the effect of treatment of leprosy patients. These services have expanded markedly in recent years both in quality and quantity to respond to the needs created by introduction of multiple drug therapy in rural and urban areas where ALERT is responsible for leprosy control work.

III. Staff:

The staffing pattern and size have changed over the years. Existing professions have increased and new functions have been introduced, requiring staff with new professional skills to respond to the needs for care and training. Addis Ababa Leprosy Hospital - ALERT Staff Development

$\begin{array}{lcc}\text { Doctors } & 2 & 11,6 \text { are Ethiopians } \\ \text { Nurses } & & 25 \\ \text { Health Officers } & 1 & 2 \\ \text { Physiotherapists } & 0 & 5 \\ \text { Orthopaedic technologists } & & 8 \\ \text { Laboratory technicians } & 1 & \\ \text { Ergotherapist } & 0 & \end{array}$


IV. Patients:

The Addis Ababa Leprosy Hospital is like a museum as one of my professors of surgery used to describe the hospital he used to work in to illustrate the wide variation in patient population and problems exposed at any one time. This is, of course, an essential basis for the teaching activities of ALERT. In the Diagnostic clinic, out of 351 new leprosy patients seen in 1985,162 were paucibacillary, 180 multibacillary and four neural cases (4). Table 1-4 provide information on the patients seen in the hospital and the out-patient clinics, being based on data in ALERT's Annual Reports for 1984 and 1985 .

Table 1. Attendance at the different out-patient clinics.

\begin{tabular}{|c|c|c|c|c|}
\hline \multicolumn{3}{|c|}{ Clinics } & \multirow{2}{*}{$\begin{array}{r}1984 \\
371\end{array}$} & \multirow{2}{*}{$\begin{array}{r}1985 \\
351\end{array}$} \\
\hline \multirow{6}{*}{ Medical } & & Leprosy & & \\
\hline & Diag- & Non-leprosy & 16,326 & 11,224 \\
\hline & nostic & Repeat leprosy & & \\
\hline & & \& non-leprosy & 12,939 & 12,616 \\
\hline & \multicolumn{2}{|c|}{ Red Medical } & 4,029 & 1,997 \\
\hline & \multicolumn{2}{|c|}{ New Case } & 277 & 314 \\
\hline \multirow{2}{*}{$\begin{array}{c}\text { Surgi- } \\
\text { cal } \\
\end{array}$} & \multicolumn{3}{|c|}{ Leprosy patients for recons- } & 254 \\
\hline & Others & cludes ulcers) & 2,209 & 1,646 \\
\hline \multirow{3}{*}{$\begin{array}{l}\text { Ophth- } \\
\text { almic }\end{array}$} & \multicolumn{2}{|c|}{ Leprosy } & 2,419 & 1,493 \\
\hline & \multicolumn{2}{|c|}{ Non-leprosy } & 5,036 & 4,135 \\
\hline & \multicolumn{2}{|c|}{ Repeat leprosy \& non-leprosy } & 2,448 & 2,783 \\
\hline
\end{tabular}

There were 614 medical admissions to the hospital of which 432 were leprosy patients, and out of 625 surgical admissions 414 were leprosy patients. 111 of 477 ophthalmic admissions were leprosy patients. 
Table 2. In-patients in the hospital

Service

Medical

Surgical

Ophthalmic
1984

783

839

359
1985

614

625

477

At this juncture, I would like to underline that there are several children among our leprosy patients (Table 3). These are just coming into life with a disease that has such a strong stigma. Thus they are coming into a socially and psychologically traumatizing environment. They need careful attention to prevent disabilities, and this observation should create an awareness to treat infectious cases early enough so as to prevent infection in the younger generation.

Table 3. Leprosy in $2-18$ years old children in 1984 and 1985

\begin{tabular}{|c|c|c|c|}
\hline Classification & Male & Female & Total \\
\hline Paucibacillary & 28 & 43 & 71 \\
\hline Multibacillary & 30 & 25 & 55 \\
\hline Neural & 3 & 0 & 3 \\
\hline Total & 61 & 68 & 129 \\
\hline
\end{tabular}

Furthermore, the cases cared for in the physiotherapy, orthopaedic appliances workshop, laboratory, ergotherapy and medico-social sections (Table 4) complete the teaching objectives of the hospital.

It is this kind of an exposure our trainees get in the hospital which will equip them with the knowledge for the planning, organization and management of leprosy work in their respective countries. 
Table 4. Activities in supportive services

\begin{tabular}{|c|c|c|c|}
\hline & Services & 1984 & 1985 \\
\hline Physiotherapy & $\begin{array}{l}\text { Voluntary muscle testing } \\
\text { and sensory testing } \\
\text { Post-operative training }\end{array}$ & $\begin{array}{r}5,042 \\
362\end{array}$ & $\begin{array}{r}5,136 \\
294\end{array}$ \\
\hline Ergotherapy & $\begin{array}{l}\text { Cooking class attendants } \\
\text { Puppet show to attendants }\end{array}$ & $\begin{array}{l}3,460 \\
2,450\end{array}$ & $\begin{array}{l}3,380 \\
2,850\end{array}$ \\
\hline $\begin{array}{l}\text { Orthopaedic } \\
\text { appliances } \\
\text { workshop }\end{array}$ & $\begin{array}{l}\text { Canvas boots } \\
\text { Sandals } \\
\text { Plastazotes }\end{array}$ & $\begin{array}{r}4,698 \\
318 \\
434\end{array}$ & $\begin{array}{r}3,294 \\
252 \\
364\end{array}$ \\
\hline Laboratory & $\begin{array}{l}\text { Skin smear for leprosy } \\
\text { other tests }\end{array}$ & $\begin{array}{l}13,709 \\
23,708\end{array}$ & $\begin{array}{r}8,163 \\
21,190\end{array}$ \\
\hline $\begin{array}{l}\text { Medico- } \\
\text { social } \\
\text { section }\end{array}$ & $\begin{array}{l}\text { Admissions and discharges } \\
\text { handled } \\
\text { Patients assisted finan- } \\
\text { cially for transport, } \\
\text { footwear etc. } \\
\text { Displaced leprosy patients } \\
\text { attached to Saturday } \\
\text { clinic }\end{array}$ & 1,013 & $\begin{array}{r}1,070 \\
660\end{array}$ \\
\hline
\end{tabular}

In summary then, this paper introduced the topic, then explored the needs, the available resources, and finally showed how these interplay in the attainment of the objectives of the hospital in this international training institution for leprosy.

\section{References}

1. Webster's New Collegiate Dictionary, 8 edit, pp. 548. G \& C. Merriam Company, Springfield, Massachusetts, USA, 1979. 
60 Taye Tadesse

2. 1985. Article I, Purpose. In the Agreement between the Ministry of Health of the Provisional Military Government of Socialist Ethiopia and The All Africa Leprosy and Rehabilitation Training Centre (including the Armauer Hansen Research Institute) concerring a continuation of the project for the provision of training in all aspects of leprosy using the existing facilities of ALERT in Addis Ababa, and the premises around it as a base.

3. Job CK. Pathogenesis of nerve lesions in leprosy. In Immunological aspects of Leprosy, Tuberculosis and Leishmaniasis. Ed. DP Humber. International Congress series no. 574, p 53 Excerpta Medica, Amsterdam, 1981. 